\title{
ANALISIS KESULITAN BELAJAR PADA MATERI OPERASI HITUNG PEMBAGIAN DI SD
}

\author{
Erika Yuliana $^{1}$, Iin Purnamasari ${ }^{2}$, Veryliana Purnamasari ${ }^{3}$ \\ Fakultas Ilmu Pendidikan, Universitas PGRI Semarang \\ email : yulianaerika95@gmail.com
}

\begin{abstract}
This research to determined the difficulty of learning in the calculation of the operation material at elementary school. The background this research is the importance of understanding the devide operations as a basis for learning mathematics. This research was a qualitative and precentage research. The result showed the difficulty of learning the devide operations includes difficulties in understanding the concept of division and difficulty inusing the principle of division; the factors that influence the learning difficulties of devide operations consists of internal factors, namely motivation, interest, and attention, while the external factors are teaching methods, teacher relations with students, and giving reinforcement feedback; a solution to overcome learning on material of devide operations that is learning with methods that are adapted to the conditions of students in order to increase motivation, interst, and attention of students in learning the devide operations, learning is carried out according to the learning steps according to Piaget's theory and using the block dienes.
\end{abstract}

Keywords: learning difficulties, mathematics, arithmetic operations

\begin{abstract}
Abstrak
Penelitian ini bertujuan untuk mengetahui kesulitan belajar pada materi operasi hitung pembagian di Sekolah Dasar. Latar belakang yang mendorong penelitian ini adalah pentingnya pemahaman operasi hitung pembagian sebagai dasar pembelajaran matematika. Penelitian ini merupakan penelitian kualitatif deskriptif dan presentase. Hasil penelitian menunjukkan kesulitan belajar operasi hitung pembagian meliputi kesulitan dalam memahami konsep pembagian dan kesulitan dalam penggunaan prinsip pembagian; faktor yang mempengaruhi kesulitan belajar operasi hitung pembagian terdiri dari faktor internal yaitu motivasi, minat, dan perhatian, sedangkan faktor eksternal yaitu metode mengajar, relasi guru dengan siswa, dan pemberian balikan penguatan; solusi untuk mengatasi kesulitan belajar pada materi operasi hitung pembagian yaitu melakukan pembelajaran dengan metode yang disesuaikan pada kondisi siswa agar dapat meningkatkan motivasi, minat, dan perhatian siswa dalam belajar operasi hitung pembagian, pembelajaran dilakukan sesuai langkah pembelajaran menurut teori piaget dan menggunakan alat peraga blok dienes.
\end{abstract}

Kata kunci: kesulitan belajar, matematika, operasi hitung pembagian 


\section{PENDAHULUAN}

Pendidikan

merupakan

kebutuhan penting sepanjang hayat bagi setiap manusia. Pendidikan dapat mengembangkan potensi sebagai manusia yang berkarakter. Setiap warga negara mempunyai hak yang sama untuk memperoleh pendidikan bermutu, dan mendapatkan kesempatan meningkatkan pendidikan sepanjang hayat (UU No. 20 Tahun 2003 BAB IV Pasal 5 tentang Sistem Pendidikan Nasional). Pendidikan bermutu dapat diperoleh sesuai UU No. 20 Tahun 2003 BAB V Pasal 12 ayat 1 poin $b$ yang menyatakan bahwa setiap peserta didik pada satuan pendidikan berhak mendapatkan pelayanan pendidikan sesuai dengan bakat, minat dan kemampuannya. Hal tersebut berarti setiap anak mendapatkan hak dalam belajar tanpa membedakan kemampuannya, seperti ada siswa yang mengalami kesulitan dalam belajar.

Matematika merupakan mata pelajaran yang diajarkan oleh siswa pada tingkatan Sekolah Dasar hingga Perguruan Tinggi. Cockroft (Abdurrahman,2012:204) menyatakan bahwa matematika perlu diajarkan kepada siswa karena (1) selalu digunakan dalam segala segi kehidupan; (2) semua bidang studi memerlukan keterampilan matematika yang sesuai; merupakan sarana komunikasi yang kuat, singkat, dan jelas; (4) dapat dijadikan untuk menyajikan informasi dalam berbagai cara; meningkatkan kemampuan berfikir logis, ketelitian, dan kesadaran keruangan; (6) memberikan kepuasan terhadap usaha memecahkan masalah yang menantang.

Pembelajaran matematika bertujuan agar peserta didik memiliki kemampuan menurut Permendiknas No. 22 (Depdiknas, 2006: 346) sebagai berikut; (1) Memahami konsep matematika, menjelaskan berkaitan antar konsep dan mengaplikasikan konsep atau algoritma, secara luwes, akurat, efisien, dan tepat dalam pemecahan masalah; (2) Menggunakan penalaran pada pola dan sifat, melakukan manipulasi matematika dalam membuat generalisasi, menyusun bukti, atau menjelaskan gagasan dan pernyataan matematika; Memecahkan masalah meliputi 
kemampuan memahami masalah, siswa takut dan tidak suka dengan merancang model matematika, pelajaran matematika.

menyelesaikan model dan menafsirkan solusi yang diperoleh;

(4) Mengkomunikasikan gagasan dengan simbol, tabel, diagram, atau media lain untuk memperjelas keadaan atau masalah; (5) Memiliki sikap menghargai kegunaan matematika dalam kehidupan, yaitu memiliki rasa ingin tahu, perhatian dan minat dalam mempelajari matematika, serta sikap ulet dan percaya diri dalam pemecahan masalah.

Berdasarkan studi pendahuluan yang dilakukan di SD Negeri Palebon 01 dengan jumlah siswa $36, \mathrm{SD}$ Negeri Palebon 02 dengan jumlah siswa 29, dan SD Negeri Palebon 03 dengan jumlah siswa 39, dapat diketahui sejumlah 13 siswa yang tidak menyukai pelajaran matematika, dan 43 siswa menyatakan bahwa pelajaran matematika adalah pelajaran yang sulit. Kesulitan belajar operasi hitung harus diatasi, karena jika kesulitan ini berlanjut, siswa akan mengalami banyak kesulitan pada materi selanjutnya, dan membuat

\section{METODE PENELITIAN}

Penelitian yang dilakukan menggunakan metode kualitatif dengan pendekatan deskriptif dan presentase. Karena penelitian menggunakan data yang tidak berupa angka, namun mendeskripsikan atau menjelaskan dalam bentuk kata-kata pada data yang diperoleh. Penelitian kualitatif merupakan suatu strategi inquiry yang menekankan pencairan makna, pengertian, konsep, karakteristik, gejala, simbol, maupun deskripsi tentang suatu fenomena; fokus dan multimetode, bersifat alami dan holistik; mengutamakan kualitas, menggunakan beberapa cara, serta disajikan secara narratif (Yusuf, 2017:329).

Mc Millan \& Schumacher dalam (Sukmadinata, 2013:96) Penelitian kualitatif mempunyai dua tujuan, yaitu: menggambarkan dan mengungkap (to describe and explore), dan menggambarkan dan menjelaskan (to describe and explain). Selain itu Sugiyono (2016: 24) mengemukakan kapan metode 
kualitatif digunakan yaitu, (1) bila masalah penelitian belum jelas, (2) untuk memahami makna di balik data yang tampak, (3) untuk memahami interaksi sosial, (4) memahami perasaan orang, (5) untuk mengembangkan teori, (6) untuk memastikan kebenaran data, (7) meneliti sejarah perkembangan.

Subjek penelitian ini adalah siswa kelas III SD Negeri Palebon 01 sejumlah 36 siswa, SD Negeri Palebon 02 sejumlah 29 siswa, dan SD Negeri Palebon 03 sejumlah 39 siswa. Teknik pengumpulan data untuk memperoleh gambaran terhadap faktor kesulitan belajar pada operasi hitung pembagian di SD Negeri Palebon 01, SD Negeri Palebon 02, dan SD Negeri Palebon 03 yaitu sebagai berikut: tes diagnostik, wawancara, dokumentasi, dan angket.

Cara untuk menganalisis suatu data yang talah dikumpulkan, Miles dan Huberman mengemukakan bahwa aktifitas dalam analisis data kualitatif dilakukan secara interaktif dan langsung secara terus menerus sampai tuntas, sehingga datanya sudah jenuh. Aktivitas dalam analisis data meliputi tahap data reduction, data display, dan conclusion drawing/verification. Berikut tahapannya: (1) Reduksi data, Dalam mereduksi data peneliti mengoreksi dan mengelompokkan lembar kerja siswa tentang kesulitan belajar pada materi operasi hitung pembagian di sekolah dasar sesuai dengan kesalahan yang dilakukan oleh siswa.

Dari hasil pekerjaan siswa dapat diketahui kesulitan dan kesalahan apa yang dilakukan oleh siswa. Data yang tidak diperlukan tidak digunakan; (2) Penyajian data, Data yang disajikan berupa analisis hasil tes diagnostik, wawancara, dokumentasi tentang kesulitan belajar pada materi operasi hitung pembagian di SD Negeri kecamatan Peudurungan Kota Semarang yang merupakaan data temuan; (3) Penarikan kesimpulan dan verifikasi, Penarikan kesimpulan pada penelitian ini dengan melakukan pencocokan analisis hasil wawancara, hasil angket dengan hasil lembar kerja siswa. Sehingga dapat ditarik kesimpulan mengenai kesulitan belajar operasi hitung pembagian di sekolah dasar yang dilakukan siswa. 


\section{HASIL DAN PEMBAHASAN}

Data pertama yang didapat merupakan data hasil angket siswa dengan bahasan 3 aspek yaitu : aspek kesulitan belajar matematika meliputi 2 indikator antara lain penanaman konsep dan penggunaan prinsip. Indikator penanaman konsep dengan persentase sebesar $50,96 \%$ untuk jawaban ya dan persentase sebesar 49,04\% untuk jawaban tidak, indikator penggunaan prinsip dengan persentase sebesar $27,88 \%$ untuk jawaban ya dan persentase sebesar $72,12 \%$ untuk jawaban tidak. Aspek yang kedua yaitu internal (siswa) meliputi 3 indikator antara lain: motivasi, minat, dan perhatian. Indikator motivasi dengan persentase sebesar $65,38 \%$ untuk jawaban ya dan persentase sebesar $34,62 \%$ untuk jawaban tidak, indikator minat dengan persentase sebesar $43,75 \%$ untuk jawaban ya dan persentase sebesar $56,25 \%$ untuk jawaban tidak, indikator perhatian dengan persentase sebesar 49,52\% untuk jawaban ya dan persentase sebesar $50,48 \%$ untuk jawaban tidak. Indikator yang selanjutnya eksternal (guru) meliputi
3 indikator antara lain: metode mengajar, relasi guru terhadap siswa, dan memberikan balikan penguatan. Indikator metode mengajar dengan persentase sebesar $27,40 \%$ untuk jawaban ya dan persentase sebesar $72,60 \%$ untuk jawaban tidak, indikator relasi guru terhadap siswa dengan persentase sebesar $41,35 \%$ untuk jawaban ya dan persentase sebesar $58,65 \%$ untuk jawaban tidak, indikator memberikan balikan penguatan dengan persentase sebesar $53,85 \%$ untuk jawaban ya dan persentase sebesar $46,15 \%$ untuk jawaban tidak.

Data berikutnya sebagai pendukung yang didapatkan memalui lembar kerja siswa dalam mengerjakan soal tes diagnostik. Berdasarkan lembar kerja siswa, pembelajaran yang dilakukan oleh guru belum berhasil, dilihat dari hasil lembar kerja siswa dalam mengerjakan 4 soal pembagian sebagai berikut: Persentase hasil hitung didapatkan dari siswa kelas III yang terdiri dari tiga SD yaitu SD Negeri Palebon 01 dengan siswa 36, SD Negeri Palebon 02 dengan siswa 29, dan SD Negeri Palebon 03 dengan 
siswa 39. Melalui perhitungan jawaban benar dan salah pada masing-masing nomor soal baik itu jawaban yang kurang tepat atau soal yang tidak dijawab. Berikut data hasil jawaban siswa didapat data hasil jawaban siswa SDN Palebon 01 dalam mengerjakan 4 soal tentang operasi hitung pembagian yaitu, pada soal nomor 1 terdapat 19 siswa yang menjawab benar, dengan persentase $52,78 \%$. Soal nomor 2 terdapat 14 siswa yang bisa menjawab benar, dengan presentase $38,89 \%$. Pada soal nomor 3 , siswa yang dapat menjawab dengan benar hanya ada 7 siswa dengan persentase 19,44\%. Sedangkan pada soal nomor 4 , hanya ada 4 siswa yang mampu menjawab benar, dengan persentase $11,11 \%$. Selanjutnya didapat data hasil jawaban siswa SDN Palebon 02 dalam mengerjakan 4 soal tentang operasi hitung pembagian yaitu, pada soal nomor 1 terdapat 10 siswa yang menjawab benar, dengan persentase $34,48 \%$. Soal nomor 2 terdapat 8 siswa yang bisa menjawab benar, dengan presentase $27,59 \%$. Pada soal nomor 3, siswa yang dapat menjawab dengan benar hanya ada 5 siswa dengan persentase 17,24\%. Sedangkan pada soal nomor 4 , hanya ada 1 siswa yang mampu menjawab benar, dengan persentase $3,4 \%$. Selanjutnya didapat data hasil jawaban siswa SDN Palebon 02 dalam mengerjakan 4 soal tentang operasi hitung pembagian yaitu, pada soal nomor 1 terdapat 24 siswa yang menjawab benar, dengan persentase $61,54 \%$. Soal nomor 2 terdapat 22 siswa yang bisa menjawab benar, dengan presentase $56,41 \%$. Pada soal nomor 3 , siswa yang dapat menjawab dengan benar hanya ada 14 siswa dengan persentase $35,90 \%$. Sedangkan pada soal nomor 4 , hanya ada 6 siswa yang mampu menjawab benar dengan persentase $15,38 \%$.

\section{SIMPULAN}

Berdasarkan hasil analisis yang telah dilakukan menunjukkan bahwa kesulitan belajar operasi hitung pembagian di sekolah dasar antara lain: kesulitan dalam memahami konsep, kesulitan dalam penggunaan prinsip, kesulitan dalam menurunkan angka, kesulitan memahami nilai tempat, kesalahan dalam memahami cara pembagian bersusun. Adapun 
faktor yang melatarbelakangi kesulitan belajar operasi hitung pembagian yaitu terdiri dari faktor internal dan faktor eksternal. Faktor internal dari siswa itu sendiri meliputi: motivasi, minat dan perhatian yang masih rendah. Sedangkan faktor eksternal dari guru terdiri dari: metode mengajar guru yang belum menggunakan media, relasi guru dengan siswa yang kurang, dan pemberian balikan penguatan yang tidak dilakukan oleh guru.

Solusi untuk mengatasi kesulitan belajar operasi hitung pembagian antara lain: mengenalkan konsep pembagian pada situasi yaitu pengukuran dan partisi, melaksanakan proses pembelajaran sesuai tahapan belajar siswa SD pada periode konkret sesuai teori belajar Piaget, menggunakan alat peraga blok dienes, mengenalkan simbol pembagian, mengajarkan siswa untuk lebih teliti, menumbuhkan motivasi, minat, perhatian belajar siswa pada materi operasi hitung dengan melakukan pengajaran melalui metode yang disesuaikan dengan kondisi siswa, dan melakukan pendekatan secara menyeluruh terhadap siswa yang mempunyai kesulitan dalam belajar operasi hitung pembagian.

Berdasarkan hasil penelitian yang diperoleh, maka saran yang dapat diberikan adalah sebagai berikut:

1. Bagi siswa diharapkan mampu menjadikan penelitian ini sebagai motivasi dalam mengembangkan dan memahami kemampuan belajar operasi hitung pembagian.

2. Bagi guru diharapkan lebih memperhatikan kesulitan belajar siswa dalam pembelajaran materi operasi hitung pembagian.

3. Bagi peneliti berikutnya diharapkan dapat lebih berinovasi dengan mengembangkan model penelitian, mengembangkan instrumen serta perangkat lain yang lebih menarik serta mendukung dalam peningkatan kemampuan belajar operasi hitung pembagian.

\section{DAFTAR PUSTAKA}

Abdurrahman, Mulyono. 2012. Anak Berkesulitan Belajar: Teori, Diagnosis, dan Remidiasinya. Jakarta: Rineka Cipta.

Depdiknas. 2006. Permendiknas No 22 Tahun 2006 Tentang 
Standar Isi. Jakarta:

Depdiknas.

Miles, M.B \& Huberman A.M. 1984. Analisis Data Kualitatif. Terjemahan oleh Tjetjep Rohendi Rohidi. 1992. Jakarta : Penerbit Universitas Indonesia.

Presiden, DPR RI. 2010. UURI No. 20 Tahun 2003 Tentang Sistem Pendidikan Nasional. Jogjakarta: Bening.

Sugiyono. 2016. Metode Penelitian Pendidikan (Pendekatan Kuantitatif, Kualitatif, dan $R \& D)$. Bandung: Alfabeta.

Sukmadinata, Nana Syaodih. 2013. Metode Penelitian Pendidikan. Bandung: PT Remaja Rosdakarya.

Yusuf, A. Muri. 2017. Metode Penelitian. Jakarta: Kenca 